\title{
Reference material for radionuclides in sediment IAEA-384 (Fangataufa Lagoon sediment)
}

P. P. Povinec, ${ }^{1, a}$ M. K. Pham, ${ }^{1}$ J. A. Sanchez-Cabeza, ${ }^{1}$ G. Barci-Funel, ${ }^{2}$ R. Bojanowski, ${ }^{3}$ T. Boshkova, ${ }^{4}$ W. C. Burnett, ${ }^{5}$ F. Carvalho, ${ }^{6}$ B. Chapeyron, ${ }^{7}$ I. L. Cunha, ${ }^{8}$ H. Dahlgaard, ${ }^{9, b}$ N. Galabov, ${ }^{10}$ L. K. Fifield, 11 J. Gastaud, ${ }^{1}$ J.-J. Geering, 12 I. F. Gomez, ${ }^{13}$ N. Green, ${ }^{14}$ T. Hamilton, ${ }^{15}$ F. L. Ibanez, ${ }^{16}$ M. Ibn Majah, ${ }^{17}$ M. John, ${ }^{18}$ G. Kanisch, ${ }^{19}$ T. C. Kenna, ${ }^{20}$ M. Kloster, ${ }^{21}$ M. Korun, ${ }^{22}$ L. Liong Wee Kwong, ${ }^{1}$ J. La Rosa, ${ }^{1, c}$ S.-H. Lee, ${ }^{1, d}$ I. Levy-Palomo, ${ }^{1}$ M. Malatova, ${ }^{23}$ Y. Maruo, ${ }^{24}$ P. Mitchell, ${ }^{25}$ I. V. Murciano, ${ }^{26}$ R. Nelson, ${ }^{27}$ A. Nouredine, ${ }^{28}$ J.-S. Oh, ${ }^{29}$ B. Oregioni, ${ }^{1, e}$ G. Le Petit, ${ }^{30}$ H. B. L. Pettersson, ${ }^{31}$ A. Reineking, ${ }^{32}$ P. A. Smedley, ${ }^{33}$ A. Suckow, ${ }^{34, f}$ T. D. B. van der Struijs, ${ }^{35}$ P. I. Voors, ${ }^{36}$ K. Yoshimizu, ${ }^{37}$ E. Wyse ${ }^{1, g}$

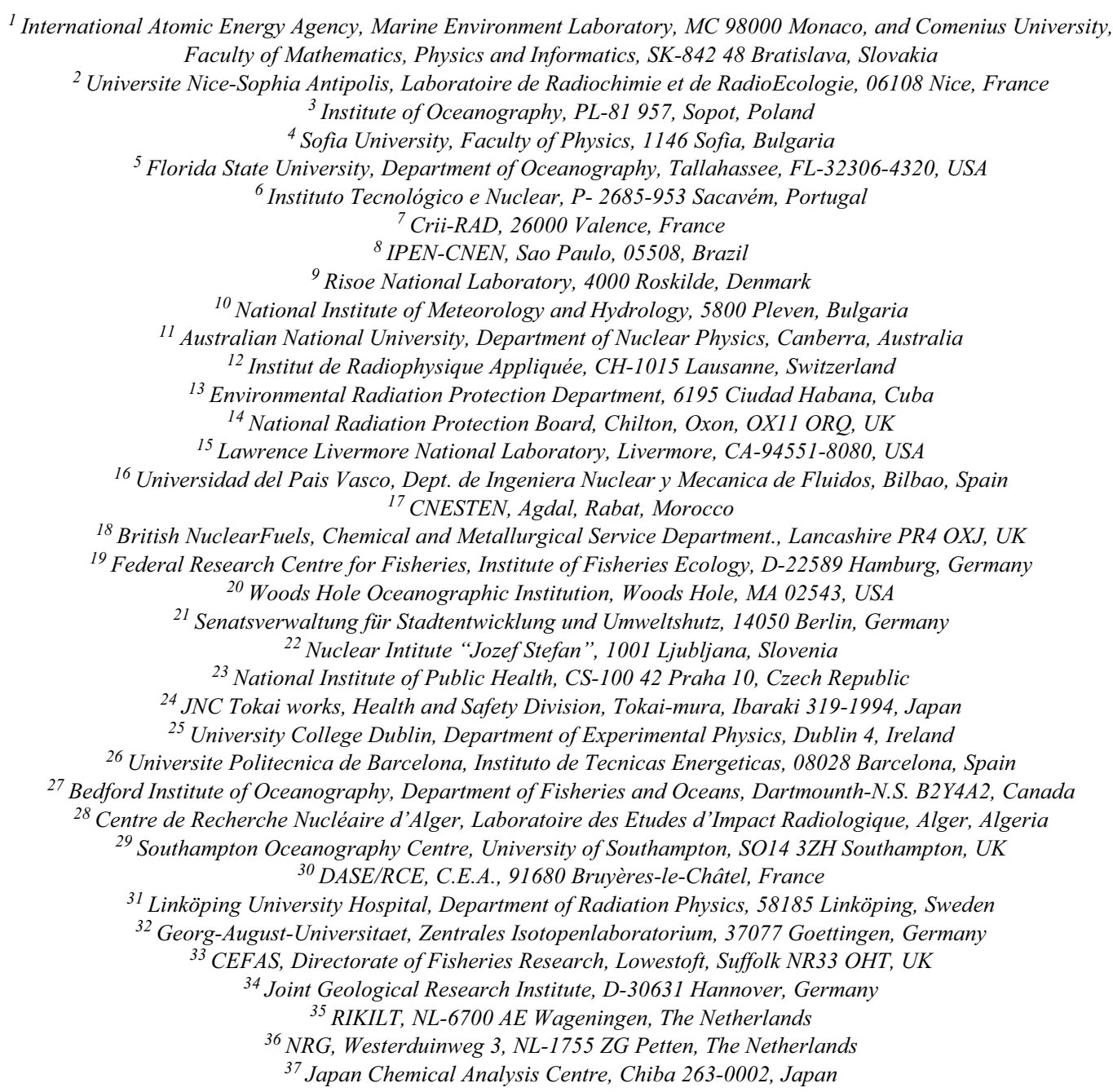

(Received July 11, 2006)

A reference material designed for the determination of anthropogenic and natural radionuclides in sediment, IAEA-384 (Fangataufa Lagoon sediment), is described and the results of certification are presented. The material has been certified for 8 radionuclides $\left({ }^{40} \mathrm{~K},{ }^{60} \mathrm{Co}\right.$, ${ }^{155} \mathrm{Eu},{ }^{230} \mathrm{Th}$, ${ }^{238} \mathrm{U},{ }^{238} \mathrm{Pu},{ }^{239+240} \mathrm{Pu}$ and $\left.{ }^{241} \mathrm{Am}\right)$. Information values are given for 12 radionuclides $\left({ }^{90} \mathrm{Sr},{ }^{137} \mathrm{Cs},{ }^{210} \mathrm{~Pb}\left({ }^{210} \mathrm{Po}\right),{ }^{226} \mathrm{Ra},{ }^{228} \mathrm{Ra},{ }^{232} \mathrm{Th},{ }^{234} \mathrm{U},{ }^{235} \mathrm{U}\right.$, ${ }^{239} \mathrm{Pu},{ }^{240} \mathrm{Pu}$ and ${ }^{241} \mathrm{Pu}$ ). Less reported radionuclides include ${ }^{228} \mathrm{Th},{ }^{236} \mathrm{U},{ }^{239} \mathrm{~Np}$ and ${ }^{242} \mathrm{Pu}$. The reference material may be used for quality management of radioanalytical laboratories engaged in the analysis of radionuclides in the environment, as well as for the development and validation of analytical methods and for training purposes. The material is available from IAEA in $100 \mathrm{~g}$ units. 


\section{Introduction}

The IAEA Marine Environment Laboratory (IAEAMEL) in Monaco has conducted intercomparison exercises on radionuclides in marine samples for many years as part of its contribution to the IAEA's programme of Analytical Quality Control Services (AQCS). ${ }^{1-4}$ An important part of the AQCS programme has been a production of Reference Materials (RMs) and their provision to radioanalytical laboratories. The RMs have been developed for different marine matrices (sediment, water, biota), with accuracy and precision required for the present state of the art of radiometrics and mass spectrometry methods. ${ }^{2-9}$

The RMs have been produced as the final products of world-wide intercomparison exercises organized over the last 30 years. A total of 44 intercomparison exercises were undertaken and $39 \mathrm{RMs}$ were produced for radionuclides in the marine environment. All required matrices (sewater, biota, sediment) were covered with radionuclide concentrations ranging from typical environmental levels to elevated levels affected by discharges from nuclear reprocessing plants.

Collection and preparation of large volume samples (over $100 \mathrm{~kg}$ ) requires to use specific methods for their pre-treatment. The required long-term availability of RMs (over 10 years) also necessitates their long-term stability. The production of a RM is a long process, covering the identification of needs, sample collection, pre-treatment, homogenization, bottling, distribution to laboratories, evaluation of data, preliminary reporting, additional analyses in expert laboratories, certification of the material, and finally issuing the RM.

In this paper we describe the RM IAEA-384 Fangataufa Lagoon sediment designed for the determination of anthropogenic and natural radionuclides in marine environment. This RM has been prepared to provide laboratories the possibility of testing the performance of their analytical methods on a sediment sample with elevated radionuclide levels due to nuclear weapons tests. Participating laboratories were requested to determine as many radionuclides as possible by radiometrics (alpha, beta and gamma-spectrometry) and

\footnotetext{
${ }^{a}$ Corresponding author. Present address: Comenius University, Faculty of Mathematics, Physics and Informatics,

Mlynska dolina F1, SK-842 48 Bratislava, Slovakia. Tel: +421260 295 544; Fax: +421 265425 882;

E-mail address: povinec@fmph.uniba.sk

${ }^{\mathrm{b}}$ Deceased in 2005.

c Present address: National Institute of Standards and Technology, Washington D.C., USA.

d Present address: Korea Research Institute of Standards and Science, Daejeon 305-340, Republic of Korea.

e Retired from IAEA in 2003.

${ }^{\mathrm{f}}$ Present address: International Atomic Energy Agency, Isotope Hydrology Laboratory, Vienna, Austria.

g Present address: Frontier Geosciences, Seattle, USA.
}

mass spectrometry (ICPMS - inductively coupled plasma mass spectrometry, TIMS - thermal ionization mass spectrometry, AMS - accelerator mass spectrometry) methods.

\section{Experimental}

\section{Description of the material}

About $158 \mathrm{~kg}$ of sediment was collected by IAEAMEL in July 1996 in Fangataufa Lagoon (French Polynesia), where nuclear weapons testing had been carried out. It was expected, therefore, that the sediment would contain elevated levels of radionuclides formed during nuclear weapons tests, such as ${ }^{60} \mathrm{Co},{ }^{90} \mathrm{Sr},{ }^{137} \mathrm{Cs}$, ${ }^{155} \mathrm{Eu},{ }^{238} \mathrm{Pu},{ }^{239+240} \mathrm{Pu},{ }^{241} \mathrm{Pu}$ and ${ }^{241} \mathrm{Am}$.

After box coring the sediment was frozen for 2 hours at $-40{ }^{\circ} \mathrm{C}$, then freeze-dried with a $+5{ }^{\circ} \mathrm{C}$ increase in temperature per hour. Secondary drying was done over 24 hours under a 0.02 mbar pressure at a constant temperature of $+40{ }^{\circ} \mathrm{C}$. The sediment was then ground into powder, sieved at $250 \mu \mathrm{m}$, homogenized under nitrogen gas and bottled in flasks under nitrogen gas (100 g per bottle).

Particle size analysis showed that about $58 \%$ of the sediment was below $63 \mu \mathrm{m}$ and $84 \%$ below $125 \mu \mathrm{m}$. The composition of the sediment is almost $100 \%$ of $\mathrm{CaCO}_{3}$ and the density is $(2.64 \pm 0.06) \mathrm{g} \cdot \mathrm{cm}^{-3}$. The moisture content of the sediment was determined by drying several aliquots in an oven at $80{ }^{\circ} \mathrm{C}$ to constant weight (1-2 days) and was found to be $1.3 \%$ at the time of sample preparation. It was recommended that the water content be checked prior to use and that all results be reported on a dry-weight (dw) basis.

\section{Sample dispatch and data return}

The sample aliquots were distributed to participating laboratories during 1997-1998. One hundred and ten laboratories world-wide agreed to participate. Each participant received $100 \mathrm{~g}$ of the sediment sample. For each radionuclide analyzed, the following information was requested: (1) average weight of sample used for analysis; (2) number of analyses; (3) massic activity (Bq $\cdot \mathrm{kg}^{-1} \mathrm{dw}$ ) corrected for blank, background etc.; (4) estimation of the total uncertainty (counting and other uncertainties); (5) description of chemical procedure and counting equipment; (6) reference standard solutions used during analysis, and (7) chemical recoveries, counting time and decay corrections.

A total of 94 sets of results were received from participants and included in the evaluation report of the intercomparsison exercise. ${ }^{7}$ High quality data from the intercomparison exercise and additional data received from expert laboratories were included for the certification process, results of which are reported in the present paper. 


\section{Data treatment}

The massic activities of 15 anthropogenic and 21 natural radionuclides were reported. The statistical programmes used for data evaluation were the same as described in previous IAEA-MEL AQCS reports. ${ }^{6-8}$ Calculations were based on the assumption of nonparametric distribution of data to which distribution-free statistics are applicable. When not provided by the laboratory, means were calculated from individual results either as arithmetic means with corresponding uncertainties when more than two results were reported, or as weighted means with weighted uncertainties in the case of only two results reported. The values below the detection limits were segregated from the results and the remaining values were checked for the presence of outliers using the box and whisker plot test. Medians were calculated from the results passing the test, rounded off to the most significant figure of the uncertainty. These values were considered to be the most reliable estimates of the true values. Confidence intervals were determined from a non-parametric sample population and were expressed as two-sided intervals representing $95 \%$ confidence limits.

Following the IUPAC ${ }^{10}$ and $\mathrm{ISO}^{11}$ recommendations for assessment of laboratory performance, the $Z$-score methodology was used in the evaluation of results. The $Z$-score was calculated according to:

$$
Z=\left(x_{i}-x_{a}\right) / s_{b}
$$

where $x_{i}$ is the robust mean of the massic activity values reported by laboratory $i, x_{a}$ is the assigned value (mean value of accepted results), and $s_{b}$ is the target standard deviation.

The selection of the right target value depends on the objectives of the exercise. For radionuclide analysis, laboratories were required to have a relative bias below $20 \%\left(s_{b}<10 \%\right)$. The uncertainty of the assigned value $\left(s_{t u}\right)$ was included in the target value for bias by: ${ }^{12}$

$$
Z=\left(x_{i}-x_{a}\right) / \sqrt{s_{b}^{2}+s_{t u}^{2}}
$$

The performance of laboratories in terms of accuracy was expressed by the $Z$-scores for each radionuclide. The performance was considered to be acceptable if the difference between the robust mean of the laboratory and the assigned value (in $s_{b}$ units) was less than or equal to two. A $Z$-score from 2 to 3 indicates that the results are of questionable quality. If $|Z|>3$, the analysis was considered to be out of control.

The Z-score distributions were symmetric (after excluding outliers) and usually with $Z$-scores below 2, indicating that the performance of the laboratories was satisfactory. A typical example of the $Z$-score analysis for ${ }^{60} \mathrm{Co}$ is shown in Fig. 1 . The $Z$-score evaluation represents a simple method which gives participating laboratories a normalized performance score for bias.

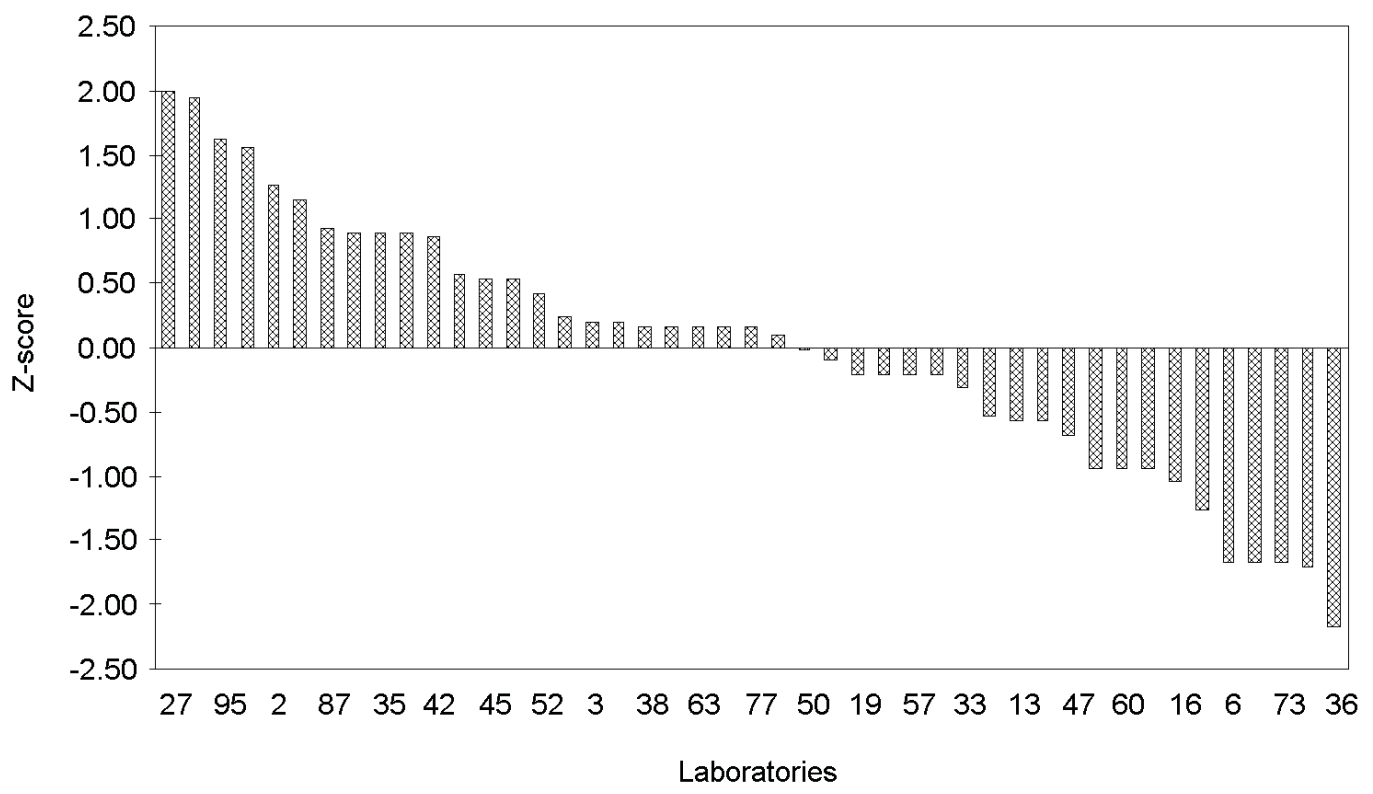

Fig. 1. $Z$-score values for ${ }^{60} \mathrm{Co}$ in IAEA-384 


\section{Criteria for certification}

The certification process was carried out following the ISO Guide $35^{13}$ using the most precise data from the intercomparison exercise and additional data from expert laboratories. For data sets comprising 5 or more accepted laboratory means, median values and confidence intervals were calculated as estimations of true massic activities. The median was considered as the certified value when: (1) at least 5 laboratory means were available, calculated from at least 3 different laboratories, and (2) the relative uncertainty of the median did not exceed $\pm 5 \%$ for activities higher than $100 \mathrm{~Bq} \cdot \mathrm{kg}^{-1} \mathrm{dw}, \pm 10 \%$ for activities from 1 to $100 \mathrm{~Bq} \cdot \mathrm{kg}^{-1} \mathrm{dw}$ and $\pm 20 \%$ for activities lower than $1 \mathrm{~Bq} \cdot \mathrm{kg}^{-1} \mathrm{dw}$.

An activity value was considered as an information value when at least 5 laboratory means of the same order of magnitude calculated from the results of at least 2 different laboratories were available.

\section{Results and discussion}

\section{Homogeneity tests}

The homogeneity of the sample was checked by measuring the activity of ${ }^{60} \mathrm{Co},{ }^{137} \mathrm{Cs},{ }^{155} \mathrm{Eu},{ }^{210} \mathrm{~Pb}$, ${ }^{226} \mathrm{Ra},{ }^{239+240} \mathrm{Pu}$ and ${ }^{241} \mathrm{Am}$ on 30 bottles taken at random. Gamma-spectrometric measurements obtained by non-destructive gamma-spectrometry were performed in 10 to $220 \mathrm{~g}$ samples, ${ }^{238} \mathrm{Pu},{ }^{239+240} \mathrm{Pu}$ and ${ }^{241} \mathrm{Am}$ were determined by alpha-spectrometry on 0.1 to $5 \mathrm{~g}$ samples. Homogeneity was determined using one-way analysis of variance. The coefficient of variation was below $10 \%$ for both gamma- and alphaspectrometrically determined radionuclides. The "between samples" variances showed no significant differences from the "within sample" variances for all radionuclides tested. Thus, the material was considered to be homogeneous for the tested radionuclides at the weight ranges used.

\section{Anthropogenic radionuclides with certified activities}

Participant results of 10 anthropogenic radionuclides $\left({ }^{90} \mathrm{Sr},{ }^{137} \mathrm{Cs},{ }^{155} \mathrm{Eu},{ }^{238} \mathrm{Pu},{ }^{239} \mathrm{Pu},{ }^{240} \mathrm{Pu},{ }^{239+240} \mathrm{Pu}\right.$, ${ }^{241} \mathrm{Pu}$ and ${ }^{241} \mathrm{Am}$ ) in Fangataufa Lagoon sediment were evaluated: 5 radionuclides $\left({ }^{60} \mathrm{Co},{ }^{155} \mathrm{Eu},{ }^{238} \mathrm{Pu}\right.$, $239+240 \mathrm{Pu}$ and ${ }^{241} \mathrm{Am}$, Table 1) were certified, and information values were given for 5 radionuclides $\left({ }^{90} \mathrm{Sr}\right.$, ${ }^{137} \mathrm{Cs},{ }^{239} \mathrm{Pu},{ }^{240} \mathrm{Pu},{ }^{241} \mathrm{Pu}$, Table 2).

As an example, Figs 2 to 4 present the evaluation results in order of ascending massic activities for ${ }^{60} \mathrm{Co}$, $239+240 \mathrm{Pu}$ and ${ }^{241} \mathrm{Am}$. Also shown are the distribution medians and corresponding confidence intervals.

${ }^{60} \mathrm{Co}$ : Data representing 45 laboratory means were used in the certification process (Fig. 2). Gammaspectrometry was used in all analyses. The data show very good homogeneity, falling less than two standard deviations from the distribution mean. The $Z$-score values were below 2.2 showing reasonable performances by the laboratories (Fig. 1). The median given as the certified value is $2.50 \mathrm{~Bq} \cdot \mathrm{kg}^{-1} \mathrm{dw}(95 \%$ confidence interval is (2.40-2.60) $\left.\mathrm{Bq} \cdot \mathrm{kg}^{-1} \mathrm{dw}\right)$.

${ }^{155} \mathrm{Eu}$ : 30 laboratory means were used in the certification process. Gamma-spectrometry was used in all analyses. The data set was homogeneous, within two standard deviations of the distribution mean. The $Z$-score values were below 2.0, showing good performances by the laboratories. The median given as the certified value is $7.0 \mathrm{~Bq} \cdot \mathrm{kg}^{-1} \mathrm{dw}(95 \%$ confidence interval is (6.7-7.3) $\left.\mathrm{Bq} \cdot \mathrm{kg}^{-1} \mathrm{dw}\right)$.

Table 1. Certified massic activities in IAEA-384 (Fangataufa Lagoon sediment)

\begin{tabular}{lccccc}
\hline \multicolumn{1}{c}{ Radionuclide } & $\begin{array}{c}\text { Mean } \pm \text { std. dev., } \\
\mathrm{Bq} \cdot \mathrm{kg}^{-1} \mathrm{dw}\end{array}$ & $\begin{array}{c}\text { Median, } \\
\mathrm{Bq}^{-1} \mathrm{~kg}^{-1} \mathrm{dw}\end{array}$ & $\begin{array}{c}95 \% \text { confidence } \\
\text { interval, } \mathrm{Bq} \cdot \mathrm{kg}^{-1} \mathrm{dw}\end{array}$ & $\begin{array}{c}\text { Number of } \\
\text { laboratory means* }\end{array}$ & $\begin{array}{c}\text { Relative } \\
\text { uncertainty, \% }\end{array}$ \\
\hline${ }^{40} \mathrm{~K}$ & $6.8 \pm 0.4$ & 6.8 & $6.5-7.1$ & 25 & 8.8 \\
${ }^{60} \mathrm{Co}$ & $2.53 \pm 0.37$ & 2.50 & $2.40-2.60$ & 45 & 8.0 \\
${ }^{155} \mathrm{Eu}$ & $7.0 \pm 0.3$ & 7.0 & $6.7-7.3$ & 30 & 8.6 \\
${ }^{230} \mathrm{Th}$ & $2.46 \pm 0.21$ & 2.50 & $2.38-2.61$ & 10 & 9.2 \\
${ }^{238} \mathrm{U}$ & $35.3 \pm 1.7$ & 35.5 & $33.4-36.8$ & 18 & 9.6 \\
${ }^{238} \mathrm{Pu}$ & $38.9 \pm 0.6$ & 39.0 & $38.6-39.6$ & 35 & 2.6 \\
${ }^{239,240} \mathrm{Pu}$ & $107 \pm 2$ & 107 & $103-110$ & 44 & 6.5 \\
${ }^{241} \mathrm{Am} * *$ & $7.1 \pm 0.8$ & 7.1 & $6.7-7.4$ & 57 & 9.9 \\
\hline
\end{tabular}

Reference date for decay correction: 1 August 1996.

* Number of accepted laboratory means which were used to calculate the certified activities and the corresponding confidence intervals.

** The value should be corrected for ingrowth from ${ }^{241} \mathrm{Pu}$. 
P. P. POVINEC et al.: REFERENCE MATERIAL FOR RADIONUCLIDES IN SEDIMENT IAEA-384 (FANGATAUFA LAGOON SEDIMENT)

Table 2. Information massic activities in IAEA-384 (Fangataufa Lagoon sediment)

\begin{tabular}{|c|c|c|c|c|c|}
\hline Radionuclide & $\begin{array}{c}\text { Mean } \pm \text { std. dev. } \\
\mathrm{Bq} \cdot \mathrm{kg}^{-1}\end{array}$ & $\begin{array}{l}\text { Median, } \\
\mathrm{Bq}^{\prime} \mathrm{kg}^{-1}\end{array}$ & $\begin{array}{l}95 \% \text { confidence } \\
\text { interval, } \mathrm{Bq} \cdot \mathrm{kg}^{-1}\end{array}$ & $\begin{array}{c}\text { Number of } \\
\text { laboratory means* }\end{array}$ & $\begin{array}{c}\text { Relative } \\
\text { uncertainty, \% }\end{array}$ \\
\hline${ }^{90} \mathrm{Sr}$ & $1.7 \pm 0.4$ & 1.7 & $1.5-1.9$ & 15 & 23 \\
\hline${ }^{137} \mathrm{Cs}$ & $0.36 \pm 0.14$ & 0.30 & $0.24-0.50$ & 26 & 87 \\
\hline${ }^{210} \mathrm{~Pb}\left({ }^{210} \mathrm{Po}\right) * *$ & $22 \pm 2$ & 22 & $21-23$ & 13 & 9.1 \\
\hline${ }^{226} \mathrm{Ra}$ & $2.5 \pm 0.6$ & 2.4 & $2.0-2.9$ & 18 & 37 \\
\hline${ }^{228} \mathrm{Ra}$ & $1.5 \pm 0.5$ & 1.6 & $0.8-2.0$ & 5 & 75 \\
\hline${ }^{232} \mathrm{Th}$ & $0.018 \pm 0.008$ & 0.022 & $0.008-0.024$ & 5 & 73 \\
\hline${ }^{234} \mathrm{U}$ & $40 \pm 5$ & 40 & $35-43$ & 18 & 20 \\
\hline${ }^{235} \mathrm{U}$ & $1.74 \pm 0.16$ & 1.70 & $1.60-1.96$ & 14 & 21 \\
\hline${ }^{239} \mathrm{Pu}$ & $97 \pm 9$ & 98 & $85-105$ & 8 & 20 \\
\hline${ }^{240} \mathrm{Pu}$ & $17.2 \pm 1.5$ & 17.5 & $15.1-18.7$ & 8 & 21 \\
\hline${ }^{241} \mathrm{Pu}$ & $56 \pm 5$ & 55 & 41-69 & 8 & 51 \\
\hline
\end{tabular}

Reference date for decay correction: 1 August 1996.

* Number of accepted laboratory means which were used to calculate the information activities and the corresponding confidence intervals.

** The value should be corrected for ingrowth from ${ }^{226} \mathrm{Ra}$.

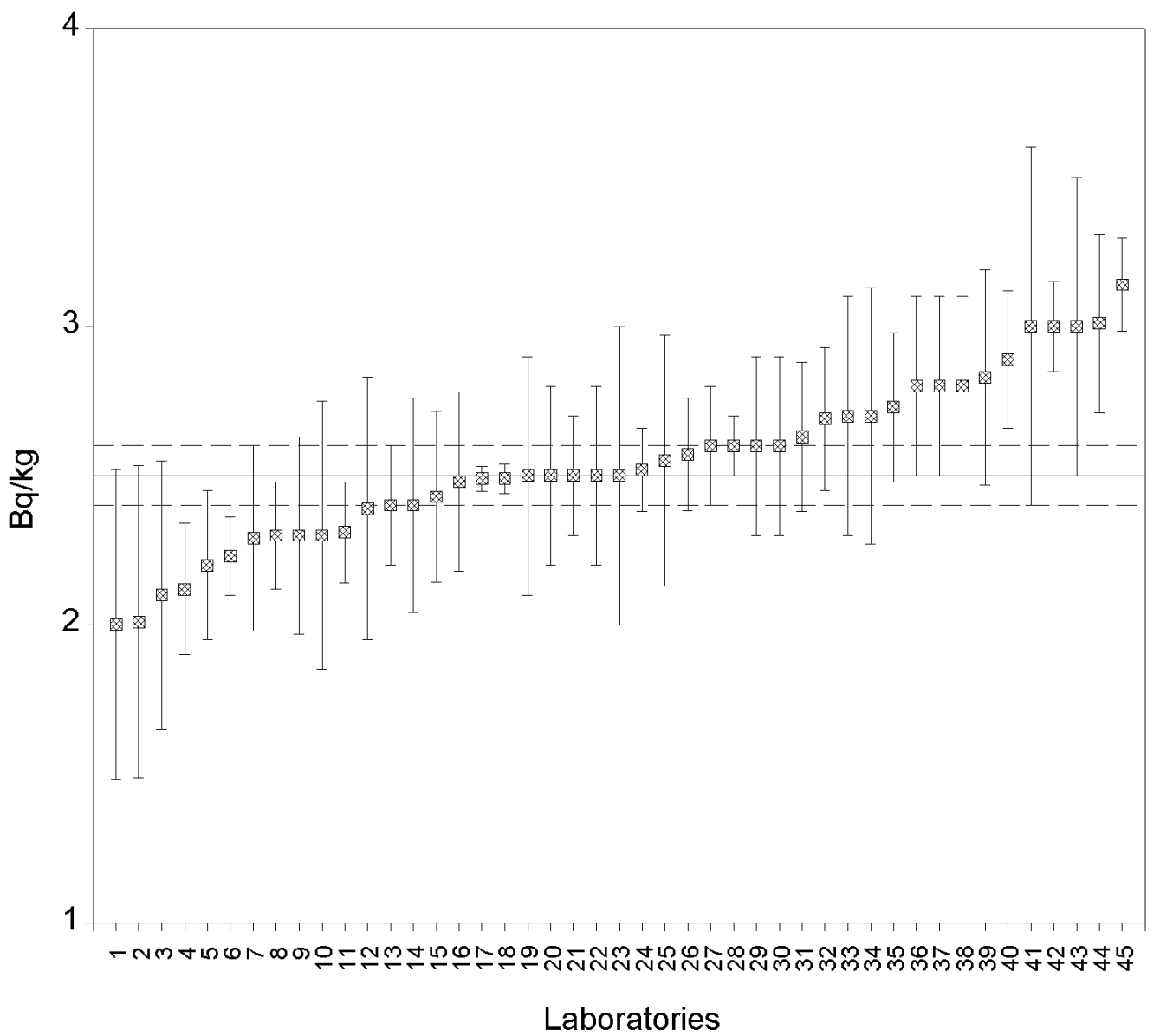

Fig. 2. Data evaluation for ${ }^{60} \mathrm{Co}$ in IAEA-384. The median (solid line) and corresponding $95 \%$ confidence intervals (dashed lines) are also shown 


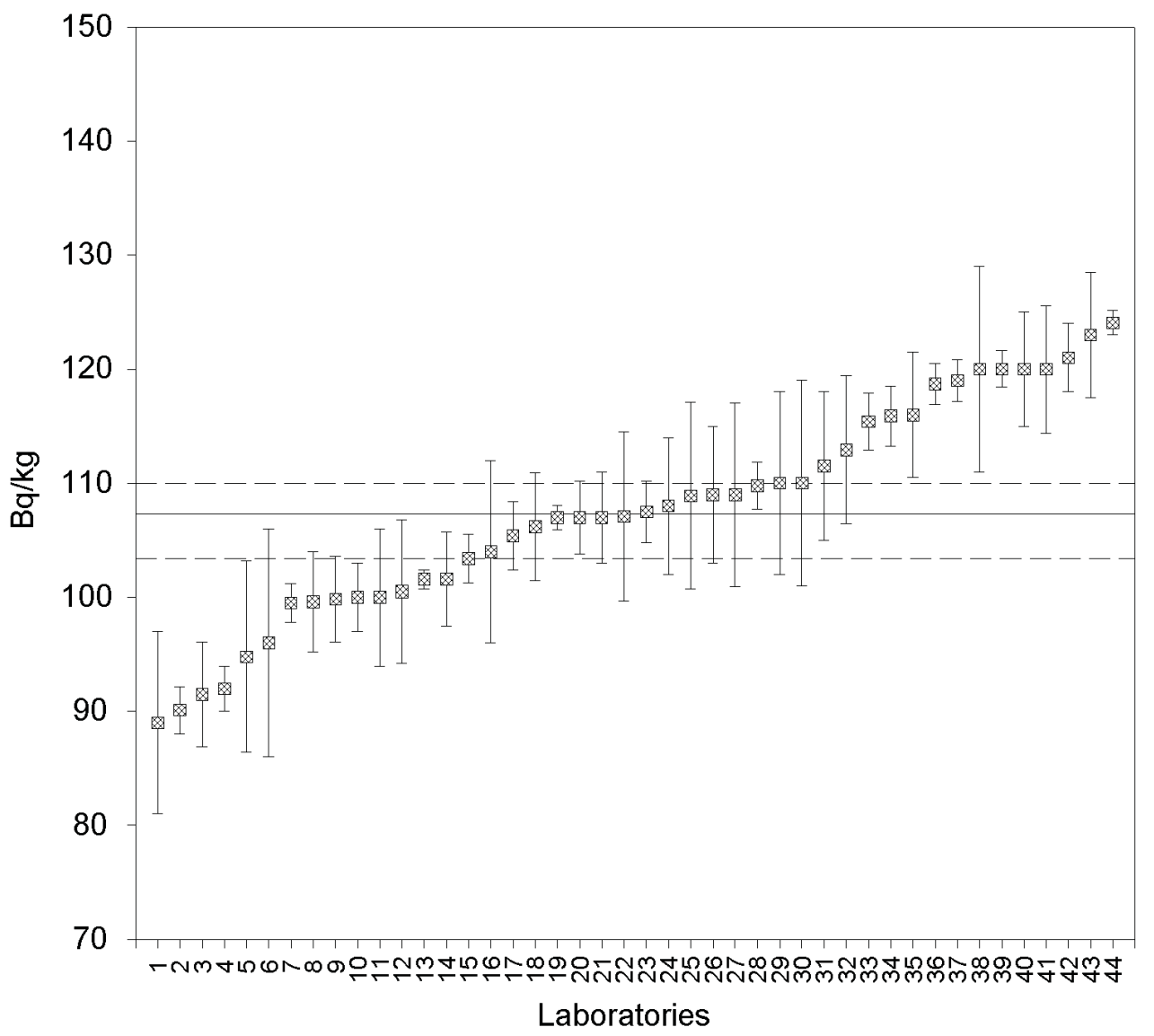

Fig. 3. Data evaluation for ${ }^{239+240} \mathrm{Pu}$ in IAEA-384. The median (solid line) and corresponding $95 \%$ confidence intervals (dashed lines) are also shown

\section{Plutonium isotopes}

The majority of participants used conventional radiochemical methods based on sample treatment, ionexchange separation followed by electrodeposition and alpha-spectrometry. Some laboratories combined ionexchange separation with liquid-liquid extraction, or used only the liquid-liquid extraction. Resins (a single TRU column or double UTEVA + TRU columns) for the separation and subsequent electrodeposition for alpha-spectrometry $\left({ }^{238} \mathrm{Pu}\right)$ and/or for direct ICPMS and AMS analysis $\left({ }^{239} \mathrm{Pu},{ }^{240} \mathrm{Pu},{ }^{241} \mathrm{Pu},{ }^{242} \mathrm{Pu}\right)$ were also used. ${ }^{14,15}$ The samples for mass spectrometry analyses were either leached from stainless steel discs after alphaspectrometry measurements, or analyzed directly in mass spectrometers. Generally, a reasonable agreement was obtained between alpha-spectrometry and mass spectrometry results, although the latter were mostly found on the right side of the distribution mean. ${ }^{16}$

${ }^{238} \mathrm{Pu}$ : 35 data sets obtained by alpha-spectrometry were evaluated. The data were homogeneous, within two standard deviations of the distribution mean. The Z- score values were below 2.2 showing reasonable performances by the laboratories. The median, given as the certified value, is $39.0 \mathrm{~Bq} \cdot \mathrm{kg}^{-1} \mathrm{dw}(95 \%$ confidence interval is (38.6-39.6) $\left.\mathrm{Bq} \cdot \mathrm{kg}^{-1} \mathrm{dw}\right)$.

$239+240$ Pu: 44 data sets obtained by alphaspectrometry, ICPMS and AMS were included in the evaluation (Fig. 3). The data were homogeneous, within two standard deviations of the distribution mean. The $Z$-score values were below 2.1 showing reasonable performances by the laboratories. The median, given as the certified value is $107 \mathrm{~Bq} \cdot \mathrm{kg}^{-1} \mathrm{dw}$ (95\% confidence interval is $\left.(103-110) \mathrm{Bq}^{\circ} \mathrm{kg}^{-1} \mathrm{dw}\right)$.

${ }^{241} \mathrm{Am}$ : 57 results (38 obtained by gammaspectrometry and 19 by alpha-spectrometry) were available for statistical treatment (Fig. 4). The data fell within less than 2 standard deviations from the distribution mean. Generally, the results obtained by gamma-spectrometry were in agreement with alphaspectrometry data. The combined $Z$-score values were below 2. The median, given as the certified value, is $7.1 \mathrm{~Bq} \cdot \mathrm{kg}^{-1} \mathrm{dw}(95 \%$ confidence interval is $(6.7-$ 7.4) $\left.\mathrm{Bq}^{\circ} \cdot \mathrm{kg}^{-1} \mathrm{dw}\right)$. 


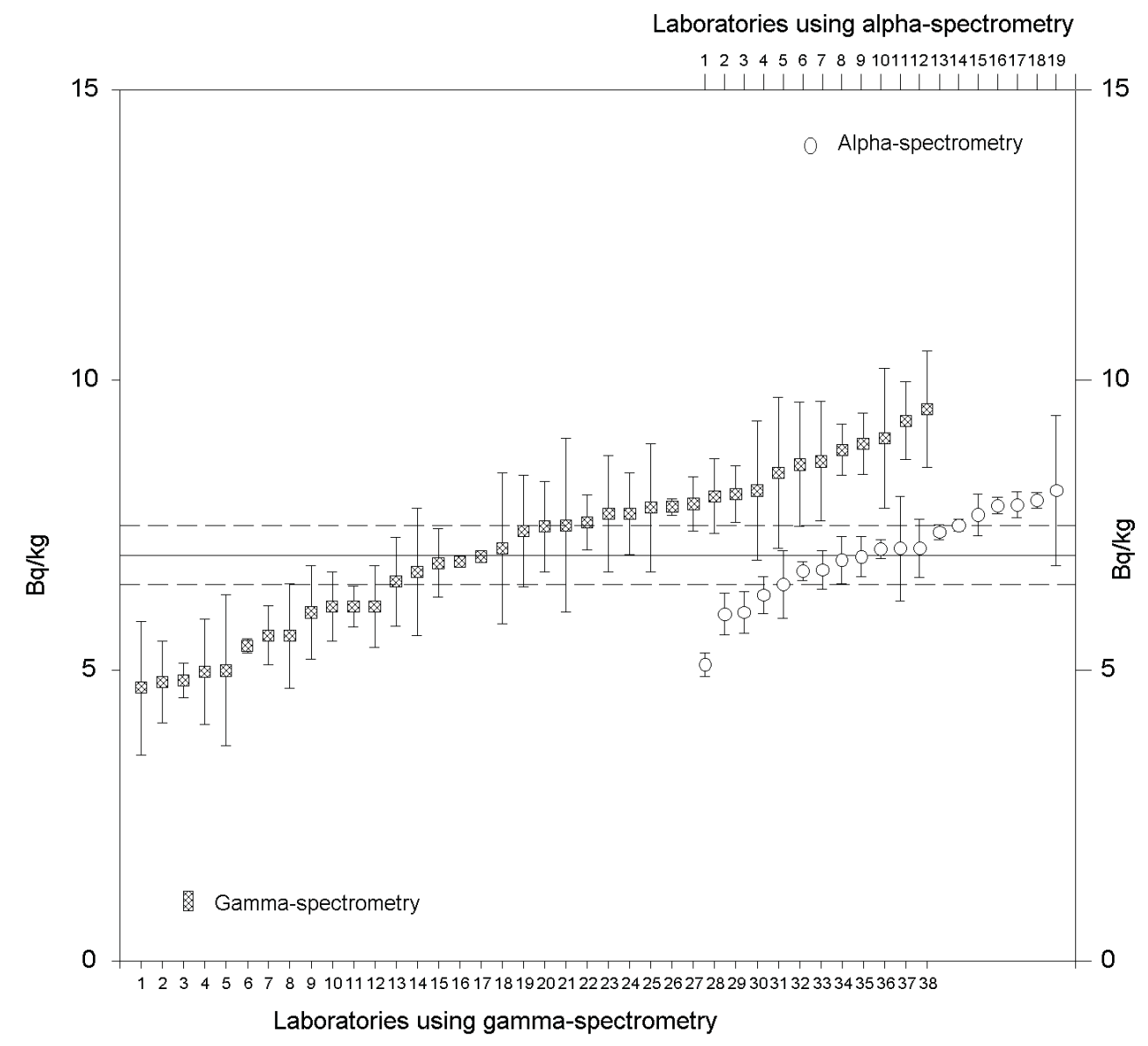

Fig. 4. Data evaluation for ${ }^{241} \mathrm{Am}$ in IAEA-384. The median (solid line) and corresponding $95 \%$ confidence intervals (dashed lines) are also shown

\section{Natural radionuclides with certified values}

Analytical results for 10 natural radionuclides in Fangataufa Lagoon sediment were evaluated: 3 radionuclides were certified $\left({ }^{40} \mathrm{~K},{ }^{230} \mathrm{Th}\right.$ and ${ }^{238} \mathrm{U}$, Table 1) and information values were estimated for 7 radionuclides $\left({ }^{210} \mathrm{~Pb}\left({ }^{210} \mathrm{Po}\right),{ }^{226} \mathrm{Ra},{ }^{228} \mathrm{Ra},{ }^{232} \mathrm{Th},{ }^{234} \mathrm{U}\right.$ and ${ }^{235} \mathrm{U}$, Table 2). As an example, Fig. 5 presents the evaluation results with the corresponding standard deviations in order of ascending massic activity for ${ }^{238} \mathrm{U}$, as obtained by alpha-spectrometry, ICPMS and TIMS.

${ }^{40} \mathrm{~K}: 25$ laboratory means, all obtained by gammaspectrometry were available for data evaluation. Some of the laboratories encountered problems with calibration and the correct estimation of the background under the ${ }^{40} \mathrm{~K}$ photopeak. The data showed reasonable homogeneity. The $Z$-score values of accepted data were below 2.1, showing reasonable performances by the laboratories. The median, given as the certified value, is $6.8 \mathrm{~Bq} \cdot \mathrm{kg}^{-1} \mathrm{dw}(95 \%$ confidence interval is $(6.5-$ 7.1) $\left.\mathrm{Bq} \cdot \mathrm{kg}^{-1} \mathrm{dw}\right)$.

${ }^{230} \mathrm{Th}$ : 10 reported laboratory means obtained by alpha-spectrometry were accepted in the evaluation. The data set was homogeneous, within 2 standard deviations of the distribution mean. The $Z$-score values were below 2.3. The median, given as the certified value, is $2.50 \mathrm{~Bq} \cdot \mathrm{kg}^{-1} \mathrm{dw}(95 \%$ confidence interval is $(2.38-$ 2.61) $\left.\mathrm{Bq} \cdot \mathrm{kg}^{-1} \mathrm{dw}\right)$.

${ }^{238} \mathrm{U}$ : 11 laboratory means obtained by gammaspectrometry, 15 obtained by alpha-spectrometry, 2 by ICPMS and 1 by TIMS were used in the evaluation (Fig. 5). As the precision and accuracy of gammaspectrometry results were low, they were excluded from certification. The $Z$-score values were below 1.8 . The median of the combined alpha and mass spectrometry data (Fig. 5) gives the certified value of $35.5 \mathrm{~Bq} \cdot \mathrm{kg}^{-1} \mathrm{dw}$ (95\% confidence interval is $(33.4-36.8) \mathrm{Bq} \cdot \mathrm{kg}^{-1} \mathrm{dw}$ ). 


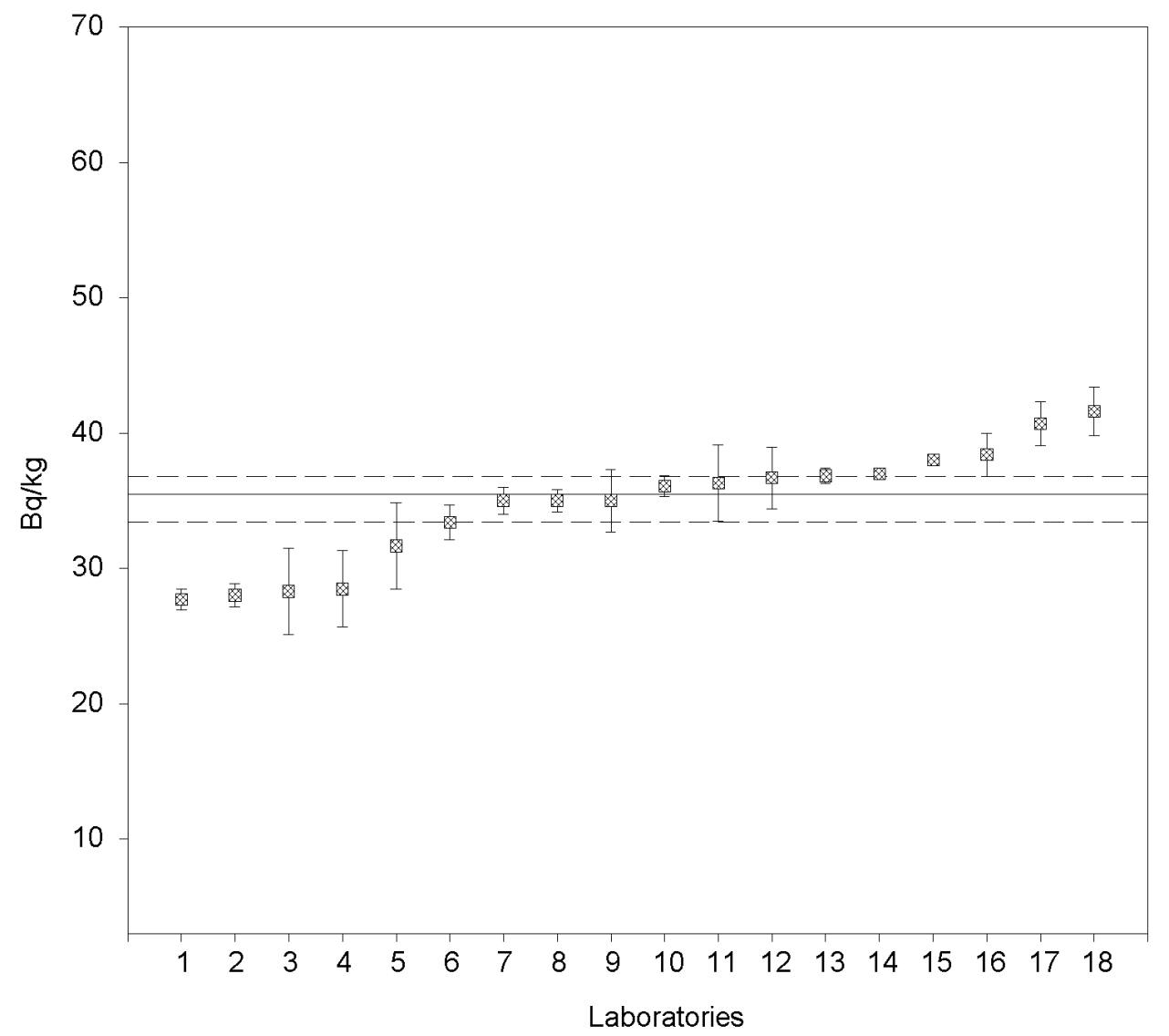

Fig. 5. Data evaluation for ${ }^{238} \mathrm{U}$ in IAEA-384. The median (solid line) and corresponding $95 \%$ confidence intervals (dashed lines) are also shown

Anthropogenic radionuclides with information values

${ }^{90} \mathrm{Sr}: 15$ laboratory means obtained by radiochemical treatment (mostly precipitation, ${ }^{90} \mathrm{Y}$ extraction, and gas or scintillation counting) were available for the evaluation. The data show reasonable homogeneity, falling less than two standard deviations from the distribution mean. The $Z$-score values were below 1.7 , showing good performances by the laboratories. The median, given as the information value, is $1.7 \mathrm{~Bq} \cdot \mathrm{kg}^{-1} \quad \mathrm{dw} \quad(95 \%$ confidence interval is (1.5-1.9) $\left.\mathrm{Bq} \cdot \mathrm{kg}^{-1} \mathrm{dw}\right)$.

${ }^{137} \mathrm{Cs}$ : The evaluated data set based on 26 laboratory means obtained by gamma-spectrometry was homogenous within two standard deviations of the distribution mean. The $Z$-score values were below 2.2, showing reasonable performances by the laboratories. The median, given as the information value, is $0.30 \mathrm{~Bq} \cdot \mathrm{kg}^{-1} \mathrm{dw} \quad(95 \%$ confidence interval is (0.24-0.50) Bq $\left.\mathrm{kg}^{-1} \mathrm{dw}\right)$.

${ }^{239} \mathrm{Pu}$ : 8 laboratory means (obtained by ICPMS and AMS) were available for data treatment (Fig. 6), all results passed the outlier test. The $Z$-score values were below 1.7. The median, given as the information value is $98 \mathrm{~Bq} \cdot \mathrm{kg}^{-1} \mathrm{dw} \quad(95 \%$ confidence interval is (85-105) $\left.\mathrm{Bq} \cdot \mathrm{kg}^{-1} \mathrm{dw}\right)$.

${ }^{240} \mathrm{Pu}$ : 8 laboratory means were available for data treatment (Fig. 6), all results passed the outlier test. The $Z$-score values were below 1.7. The median, given as the information value is $17.5 \mathrm{~Bq} \cdot \mathrm{kg}^{-1} \mathrm{dw}$ ( $95 \%$ confidence interval is (15.1-18.7) $\left.\mathrm{Bq}^{\cdot} \mathrm{kg}^{-1} \mathrm{dw}\right)$.

${ }^{241} \mathrm{Pu}$ : $\mathrm{As}{ }^{241} \mathrm{Pu}$ is pure beta-emitter, mainly liquid scintillation spectrometry (LSS) was used for its determination (either directly on liquid samples, on discs, or from leached discs after alpha-spectrometry analysis). Alpha-spectrometry of the daughter ${ }^{241} \mathrm{Am}$, and ICPMS analyses were also used. Eight laboratory means were available for the evaluation, but as some of the ICPMS results were affected by analytical problems (e.g., contamination, calibration, etc.), they were not included in the calculation of the median. The $Z$-score values were below 1.5. The median given as the information value is $55 \mathrm{~Bq} \cdot \mathrm{kg}^{-1} \mathrm{dw}(95 \%$ confidence interval is (41-69) $\mathrm{Bq}^{\circ} \mathrm{kg}^{-1} \mathrm{dw}$ ). 

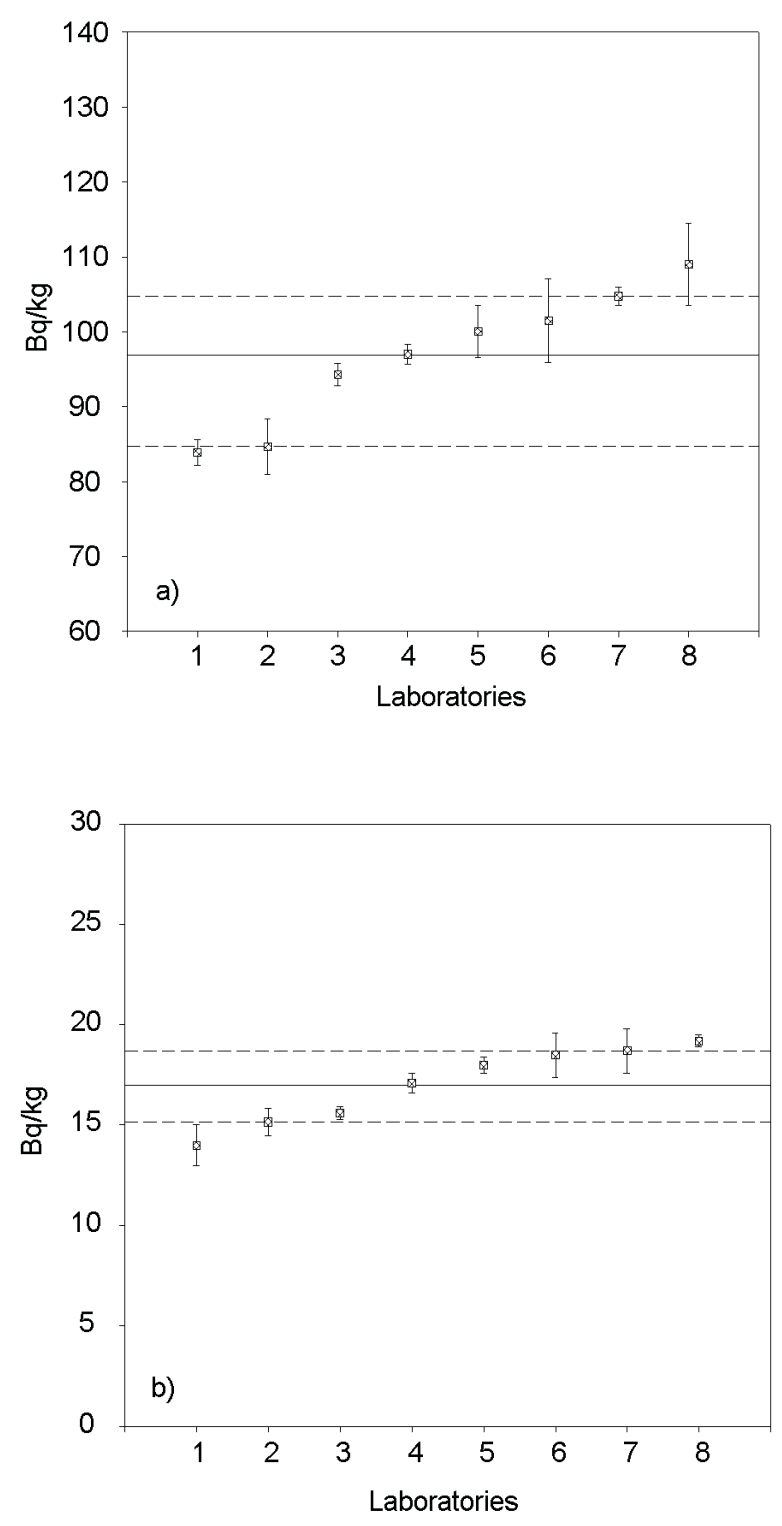

Fig. 6. Data evaluation for ${ }^{239} \mathrm{Pu}(\mathrm{a})$ and ${ }^{240} \mathrm{Pu}(\mathrm{b})$ in IAEA-384. The median (solid line) and corresponding $95 \%$ confidence intervals (dashed lines) are also shown

\section{Natural radionuclides with information values}

${ }^{210} \mathrm{~Pb}$ and ${ }^{210} \mathrm{Po}: 27$ and 7 laboratory means were available for ${ }^{210} \mathrm{~Pb}$ and ${ }^{210} \mathrm{Po}$, respectively. Mostly gamma- and alpha-spectrometry (by ${ }^{210} \mathrm{Po}$ ingrowth) were used for ${ }^{210} \mathrm{~Pb}$, and alpha-spectrometry for ${ }^{210} \mathrm{Po}$. The $Z$-score values were below 1.7. Taking into account the time elapsed between collection and analysis of the sediment sample, we assumed that ${ }^{210} \mathrm{~Pb}$ and ${ }^{210} \mathrm{Po}$ were in secular equilibrium. As the precision of alphaspectrometry results was much better, the median was calculated from 13 laboratory means obtained by alphaspectrometry only. The median given as the information value is $22 \mathrm{~Bq} \cdot \mathrm{kg}^{-1} \mathrm{dw}(95 \%$ confidence interval is $(21-$ 23) $\left.\mathrm{Bq} \cdot \mathrm{kg}^{-1} \mathrm{dw}\right)$. Although the relative uncertainty for ${ }^{210} \mathrm{~Pb}\left({ }^{210} \mathrm{Po}\right)$ is below $10 \%$, these radionuclides are listed in Table 2 with the information value only as two corrections should be applied during a storage time: (1) a correction for ${ }^{210} \mathrm{~Pb}$ decay (the half-life $22.2 \mathrm{y}$ ); and (2) a correction for in-growth of ${ }^{210} \mathrm{~Pb}$ from ${ }^{226} \mathrm{Ra}$.

${ }^{226} \mathrm{Ra}$ : 18 laboratory means obtained by gammaspectrometry (including ${ }^{214} \mathrm{Bi}$ measurements) were evaluated. The $Z$-score values were below 2 . The median given as the information value is $2.4 \mathrm{~Bq} \cdot \mathrm{kg}^{-1} \mathrm{dw}(95 \%$ confidence interval is (2.0-2.9) $\left.\mathrm{Bq}^{\circ} \mathrm{kg}^{-1} \mathrm{dw}\right)$.

${ }^{228} \mathrm{Ra}$ : 5 laboratory means obtained by gammaspectrometry were evaluated. The median given as the information value is $1.6 \mathrm{~Bq} \cdot \mathrm{kg}^{-1} \mathrm{dw}$ (95\% confidence interval is $\left.(0.8-2.0) \mathrm{Bq} \cdot \mathrm{kg}^{-1} \mathrm{dw}\right)$.

${ }^{232} \mathrm{Th}$ : Alpha-spectrometry, gamma-spectrometry and mass spectrometry techniques were used in analyses. Only 5 laboratory means were accepted in the certification, 3 produced by alpha-spectrometry and 2 by ICPMS. The $Z$-score values were below 1.4 , showing good performances by the laboratories. The median given as the information value is $0.022 \mathrm{~Bq} \cdot \mathrm{kg}^{-1} \mathrm{dw}$ ( $95 \%$ confidence interval is $\left.(0.008-0.024) \mathrm{Bq} \cdot \mathrm{kg}^{-1} \mathrm{dw}\right)$.

${ }^{234} U$ : 18 laboratory means were accepted for the evaluation. Total dissolution followed by alphaspectrometry, with the exception of 3 results obtained by ICPMS, were used in the analysis. The $Z$-score values were below 1.8 showing good performances by the laboratories. The median, given as the certified value is $40 \mathrm{~Bq} \cdot \mathrm{kg}^{-1} \mathrm{dw} \quad(95 \%$ confidence interval is (35-43) $\left.\mathrm{Bq} \cdot \mathrm{kg}^{-1} \mathrm{dw}\right)$.

${ }^{235} \mathrm{U}: 17$ gamma-spectrometry results, 11 alphaspectrometry, 2 ICPMS and 1 TIMS results were used in the evaluation. The $Z$-score values were below 2 . As the precision and accuracy of gamma-spectrometry measurements was low, the median was calculated using the alpha and mass spectrometry results only. The median given as the information value is $1.70 \mathrm{~Bq} \cdot \mathrm{kg}^{-1} \quad \mathrm{dw} \quad(95 \%$ confidence interval is (1.60-1.96) $\left.\mathrm{Bq} \cdot \mathrm{kg}^{-1} \mathrm{dw}\right)$.

\section{Less frequently reported radionuclides}

${ }^{228} \mathrm{Th}$ : The average massic activity from 4 laboratory means obtained by alpha- and gamma-spectrometry is (1.6 \pm 1.4$) \mathrm{Bq} \cdot \mathrm{kg}^{-1} \mathrm{dw}$.

${ }^{236} U$ : One result obtained by AMS showed a massic activity of $(8.4 \pm 1.7) \cdot 10^{-6} \mathrm{~Bq} \cdot \mathrm{kg}^{-1} \mathrm{dw}$.

${ }^{237} \mathrm{~Np}$ : Three laboratory means obtained by alphaspectrometry were evaluated. The average massic activity is $(0.010 \pm 0.003) \mathrm{Bq} \cdot \mathrm{kg}^{-1} \mathrm{dw}$.

${ }^{242} \mathrm{Pu}$ : One result obtained by ICPMS and one by AMS gave massic activities of $(1.9 \pm 0.5) \mathrm{mBq} \cdot \mathrm{kg}^{-1} \mathrm{dw}$ and $(0.7 \pm 0.3) \mathrm{mBq} \cdot \mathrm{kg}^{-1} \mathrm{dw}$, respectively. 


\section{Isotopic ratios}

${ }^{137} \mathrm{Cs} /{ }^{90} \mathrm{Sr}$ : The average ${ }^{137} \mathrm{Cs} /{ }^{90} \mathrm{Sr}$ activity ratio is $0.21 \pm 0.08$, much lower than the global fallout value $1.5,{ }^{17}$ due to the enhanced concentration of ${ }^{90} \mathrm{Sr}$ in the sediment of Fangataufa Lagoon.

${ }^{137} \mathrm{Cs} / 239,240 \mathrm{Pu}$ : The average ${ }^{137} \mathrm{Cs} / 239,240 \mathrm{Pu}$ activity ratio is $0.003 \pm 0.001$, lower by 3 orders of magnitude than the global fallout ratio ${ }^{17}$ due to the enhanced concentration of plutonium in the sediment.

${ }^{238} \mathrm{Pu} / 239+240 \mathrm{Pu}$ : The average ${ }^{238} \mathrm{Pu} /{ }^{239+240} \mathrm{Pu}$ activity ratio is $0.363 \pm 0.003$, much higher than the global fallout value $0.025,{ }^{17}$ confirming that most of the plutonium found in the lagoon is due to local fallout from nuclear weapons tests.

${ }^{241} \mathrm{Pu} / 239,240 \mathrm{Pu}$ : The average ${ }^{241} \mathrm{Pu} /{ }^{239,240} \mathrm{Pu}$ activity ratio is $0.52 \pm 0.06$, much smaller than the global fallout value $15,{ }^{18}$ due to the enhanced concentration of ${ }^{239} \mathrm{Pu}$ in the sediment.

${ }^{241} \mathrm{Am} / 239,240 \mathrm{Pu}$ : The average ${ }^{241} \mathrm{Am} /{ }^{239+240} \mathrm{Pu}$ activity ratio is $0.066 \pm 0.003$, much smaller than the global fallout value $0.40,{ }^{17}$ again due to the enhanced concentration of ${ }^{239} \mathrm{Pu}$ in the sediment.

${ }^{240} \mathrm{Pu} /{ }^{239} \mathrm{Pu}$ : The average ${ }^{240} \mathrm{Pu} /{ }^{239} \mathrm{Pu}$ activity ratio from 8 measurements made by ICPMS and AMS and 1 by high resolution alpha-spectrometry is $0.177 \pm 0.002$, much lower than the global fallout ratio of $0.66 .{ }^{18}$ The average ${ }^{240} \mathrm{Pu} /{ }^{239} \mathrm{Pu}$ mass ratio is $0.049 \pm 0.001$ (the global fallout ratio is 0.180$)^{18}$ confirming that the origin of plutonium in Fangataufa Lagoon is due to local fallout from nuclear weapons tests.

\section{Conclusions}

The accurate and precise determinations of radionuclide concentrations in marine samples are essential for the assessments of the presence of radionuclides in the marine environment and their use in studies of oceanographic processes. To address the problem of data quality, and to assist IAEA Member States in verifying the performance of their laboratories, the IAEA-MEL has been developing RMs, which are important benchmark in quality management of laboratories.

Fangataufa Lagoon sediment sample (IAEA-384) was described in this paper and data on anthropogenic and natural radionuclides were evaluated. The medians of massic activities with $95 \%$ confidence intervals were chosen as the most reliable estimates of the true values. IAEA-384 Fangataufa Lagoon sediment was certified as a RM for 8 radionuclides $\left({ }^{40} \mathrm{~K},{ }^{60} \mathrm{Co},{ }^{155} \mathrm{Eu},{ }^{230} \mathrm{Th}\right.$, ${ }^{238} \mathrm{U},{ }^{238} \mathrm{Pu},{ }^{239+240} \mathrm{Pu}$ and $\left.{ }^{241} \mathrm{Am}\right)$, and information values were estimated for 12 radionuclides $\left({ }^{90} \mathrm{Sr},{ }^{137} \mathrm{Cs}\right.$, ${ }^{210} \mathrm{~Pb}\left({ }^{210} \mathrm{Po}\right),{ }^{226} \mathrm{Ra},{ }^{228} \mathrm{Ra},{ }^{232} \mathrm{Th},{ }^{234} \mathrm{U},{ }^{235} \mathrm{U},{ }^{239} \mathrm{Pu}$,
${ }^{240} \mathrm{Pu}$ and ${ }^{241} \mathrm{Pu}$ ). This $\mathrm{RM}$ may be used for quality management of radioanalytical laboratories, assessing the validity of radioanalytical methods and identifying weaknesses in methodologies, helping to detect training needs, and up-grading the quality of laboratories' performance. The material is available from the IAEA in $100 \mathrm{~g}$ units.

*

The participants and laboratories which responded to the intercomparison exercise and contributed their time and facilities to the present work are hereby highly acknowledged. Special acknowledgement is given to the Commissariat à l'Energie Atomique (France) for their support during the sampling campaign at Mururoa and Fangataufa Atolls. The IAEA is grateful for the support provided to its Marine Environment Laboratory by the Government of the Principality of Monaco.

\section{References}

1. P. P. Povinec, J. Gastaud, M. K. Pham, in: Marine Pollution, IAEA-TECDOC-1094, IAEA, Vienna, 1999, p. 87.

2. P. P. Povinec, M. K. Pham, J. Radioanal. Nucl. Chem., 248 (2001) 211.

3. M. K. Pham, P. P. Povinec, Bulletin de BNM, 127 (2003) 210.

4. J. A. Sanchez-Cabeza, M. K. Pham, P. P. Povinec, J. Accredit. Quality Assurance (in press).

5. P. P. Povinec, C. Baddie, A. Baeza, G. Barci-Funel, T. D. Bergan, R. Bojanowski, W. C. Burnett, J. EikenberG,

L. K. Fifield, V. Serradel, J. Gastaud, I. Goroncy,

J. HermanN, M. A. HotchKis, T. K. IKAHEIMONEN,

E. Jakobson, J. Kalimbadjan, J. J. La Rosa, S.-H. Lee,

L. Liong WeE KWong, W. M. Lueng, S. P. Nielsen,

A. Noureddine, P. K. Pham, J.-N. ROHOU,

J. A. SAnchez-CabezA, J. SuOmela, M. SuplinsKa, E. Wyse, J. Radioanal. Nucl. Chem., 251 (2002) 369.

6. P. P. Povinec, M. K. Pham, S. Ballestra, Report on the Intercomparison Run and Certified Reference Material IAEA-381, Radionuclides in Irish Sea Water, IAEA/MEL/66, IAEA, Vienna, 1999.

7. P. P. Povinec, M. K. Pham, Report on the Intercomparison Run IAEA-384, Radionuclides in Fangataufa Lagoon Sediment, IAEA/MEL/68, IAEA, Vienna, 2000.

8. M. K. Pham, J. La Rosa, S.-H. LeE, P. P. Povinec, Report on the Worldwide Intercomparison IAEA-414, Radionuclides in Mixed Fish from the Irish Sea and the North Sea, IAEA/MEL/73, IAEA, Vienna, 2004.

9. M. K. Pham, J. A. SANChEZ-CABEZA, P. P. POVINEC, D. Arnold, M. Benmansour, R. Bojanowski, F. Carvalho, C. K. Kim, M. Esposito, J. Gastaud, G. J. HaM, A. G. Hegde, E. Holm, D. Jaskierowicz, G. Kanish, M. Llaurado, J. LA Rosa, S.-H. Lee, C. G. LeOnARTe, L. Liong WeE Kwong, G. Le Petit, Y. Maruo, S. P. Nielsen, J.-S. Oh, B. Oregioni, J. Palomares, H. B. L. Pettersson, T. Ryan, T. SAndor, H. Satake, J. Schikowski, B. Skwarzec, P. A. Smedley, N. VAJdA, E. Wyse, Appl. Radiation Isotopes, 64 (2006) 1253.

10. M. Thompson, R. Wood, J. Pure Appl. Chem., 65 (1993) 2123. 
P. P. POVINEC et al.: REFERENCE MATERIAL FOR RADIONUCLIDES IN SEDIMENT IAEA-384 (FANGATAUFA LAGOON SEDIMENT)

11. ISO, Proficiency Testing and Interlaboratory Comparisons, Guide 43, ISO/IEC, Geneva, 1997.

12. W. P. Cofino, D. E. Wells, Mar. Pollut. Bull., 29 (1994) 149.

13. ISO, Certification of Reference Materials - General and Statistical Principles, Guide 35, ISO, Geneva, 1989.

14. S.-H. Lee, J. La Rosa, J. Gastaud, P. P. Povinec, J. Radioanal. Nucl. Chem., 263 (2005) 419.

15. J. La Rosa, J. Gastaud, L. Lagan, S.-H. Lee, I. LeVy-Palomo, P. P. PovineC, J. Radioanal. Nucl. Chem., 263 (2005) 427.
16. P. P. Povinec, J. Radioanal. Nucl. Chem., 263 (2005) 413.

17. P. P. Povinec, H. D. Livingston, S. Shima, M. Aoyama, J. Gastaud, I. Goroncy, K. Hirose, L. Huynh-NgOC, Y. Ikeuchi, T. Ito, J. LA Rosa, L. Liong WeE Kwong, S.-H. Lee, H. Moriya, S. Mulsow, B. Oregioni, H. Pettersson, O. Togawa, Deep Sea Res., II 50 (2003) 2607.

18. S.-H. Lee, P. P. Povinec, E. Wyse, M. K. Pham, G.-H. Hong, C.-S. Chung, S.-H. KIM, H. J. LeE, Mar. Geol., 216 (2005) 249. 